\title{
Relationship of Attachment Styles and Personality Traits With Heroin Use Disorder
}

\author{
Bağlanma Biçimleri ve Kişilik Özelliklerinin Eroin Kullanım \\ Bozukluğu ile İlişkisi
}

Tuğçe Toker Uğurlu ${ }^{1}$, F. Figen Ateşçi², Gülizar Zengin ${ }^{3}$, Çiğdem Tekkanat ${ }^{4}$

\begin{abstract}
:
Insecure attachment styles and psychopathological personality traits are observed more frequently in patients who use heroin as one of the most frequently used addictive substances. Nevertheless the relationship between attachment styles and personality traits in heroin users is not clear. The aim of the study is compare attachment styles and personality traits of patients diagnosed with heroin use disorder with those of the healthy controls. The data of 23 of 52 cases diagnosed with heroin use disorder due to Minnesota Multiphasic Personality Inventory (MMPI) invalidity and lack of data were excluded and the study was completed with 29 cases. With the exclusion of the data of 13 of the 47 controls for the same reasons, 34 healty individuals of similar age and gender were included in the study. The sociodemographic data form, MMPI and Experiences in Close Relationships-Revised (ECR-R) were applied on the participants. Hypochondriasis, depression, hysteria, psychopathic deviate, paranoia, schizophrenia and social introversion were observed to be higher in the patient group. Ambivalent attachment was determined to be related with hysteria, depression, schizophrenia, paranoia, psychasthenia and social introversion in the patient group; avoidant attachment was determined to be related with psychasthenia and social introversion. In addition to the attachment that developed in the first years of life, personality traits that were innate but developed with environmental factors especially during adolescence were found to be more predictive for heroin addiction.
\end{abstract}

Keywords: Attachment, dependence, personality, opioid

\footnotetext{
${ }^{1}$ Asst. Prof., Department of Psychiatry, Faculty of Medicine, Pamukkale University, Denizli-Turkey, Orcid İd: 0000-00034458-088X

${ }^{2}$ Prof., Department of Psychiatry, Faculty of Medicine, Pamukkale University, Denizli-Turkey, Orcid İd: 0000-0001-66816350

${ }^{3}$ Dr., Department of Psychiatry, Aksaray Training and Research Hospital, Aksaray-Turkey, Orcid İd: 0000-0003-0274-4081

${ }^{4}$ B.A., Department of Psychiatry, Faculty of Medicine, Pamukkale University, Denizli-Turkey, Orcid İd: 0000-0002-33889163

Address of Correspondence/Yazışma Adresi: Pamukkale University Habib Kızıltaş Psychiatry Hospital Pamukkale, DenizliTurkey, E-mail: tugtoker@gmail.com

Date of Received/Geliş Tarihi: 01.03.2021, Date of Revision/Düzeltme Tarihi: 06.04.2021, Date of Acceptance/Kabul Tarihi: 29.08.2021, Date of Online Publication/Çevirimiçi Yayın Tarihi: 01.09.2021

Citing/Referans Gösterimi: Uğurlu-Toker, T., Ateşçi, F, F., Zengin, G. Tekkanat, Ç. (2021). Relationship of attachment styles and personality traits with heroin use disorder, Cyprus Turkish Journal of Psychiatry \& Psychology, 3(3): 203-211
} (C) 2021 The Author(s). Published by Cyprus Mental Health Institute / Cyprus Turkish Journal of Psychiatry and Psychology (www.ktppdergisi.com). This article is an open access article
distributed under the terms and conditions of the Creative Commons Attribution 4.0 license which permits use, sharing, adaptation, distribution and reproduction in any medium or format, provided the original work is properly cited and is not used for commercial purposes. http://creativecommons.org/licenses/by/4.0/ 


\section{Öz:}

En sık kullanılan bağımlılık yapıcı maddelerden biri olarak eroin kullanan hastalarda güvensiz bağlanma stilleri ve psikopatolojik kişilik özellikleri daha sık görülmektedir. Bununla birlikte, eroin kullananlarda bağlanma stilleri ile kişilik özellikleri arasındaki ilişki net değildir. Çalışmanın amacı, eroin kullanım bozukluğu tanısı alan hastaların bağlanma stilleri ve kişilik özelliklerinin sağlıklı kontrollerle karşılaştırılmasıdır. Minnesota Çok Yönlü Kişilik Envanteri (MMPI) test geçersizliği ve veri eksikliği nedeniyle eroin kullanım bozukluğu tanısı alan 52 olgunun 23'ünün verileri çalışma dışı bırakıldı ve çalışma 29 vaka ile tamamlandı. Aynı nedenlerle 47 kontrolden 13'ünün verileri çalışma dışı bırakılarak, benzer yaş ve cinsiyetteki 34 sağlıklı birey çalışmaya dahil edildi. Katılımcılara sosyodemografik veri formu, MMPI ve Yakın İlişsilerde Yaşantılar Envanteri II (YIYE-II) uygulandı. Hipokondriazis, depresyon, histeri, psikopatik sapma, paranoya, şizofreni ve sosyal içe dönüklük alt ölçekleri vaka grubunda anlamlı olarak daha yüksek saptanmıştır. Vaka grubunda kaygılı bağlanma histeri, depresyon, şizofreni, paranoya, psikasteni ve sosyal izolasyon ile ilişkili bulunurken, kaçıngan bağlanma ise psikasteni ve sosyal izolasyon ile ilişkili bulunmuştur. Yaşamın ilk yıllarında gelişen bağlanmanın yanı sıra, doğuştan gelen ancak özellikle ergenlik döneminde çevresel faktörlerle gelişen kişilik özelliklerinin eroin bağımlılığı için daha yordayıcı olduğu görülmüştür.

Anahtar Kelimeler: Bağlanma, bağımlılık, kişilik, opiyat

\section{Introduction}

Attachment theory has first been developed by John Bowlby and Mary Ainsworth and is defined as continuous, strong and deep emotional bond established with significant others and first with the caregiver geared towards adaptation to stay alive which manifests itself with the search for intimacy of the child and which becomes evident under stress (Fearon \& Roisman, 2017; Antonucci, Taurisano, Coppola \& Cassibba, 2018; Sümer, Oruçlular \& Çarpar, 2015; Çam \& Aydoğdu, 2015; Kesebir, Kavzoğlu \& Üstündağ, 2011). It is considered that the quality of the relationship of the individual established early on with the caregiver, in other words the cognitive, emotional and behavioral effects of the attachment system strongly manifests itself in the form of the relationships of the individual established with others in later stages of life. While some are relatively safe, comfortable in their close relations and open to receive help from others in times of stress, some are relatively insecure and uneasy when opening up to others (Szepsenwol \& Simpson, 2018; Fraley \& Roisman, 2019; Sümer et al., 2015). It can be seen that the shortcomings and setbacks in the relationship established with the caregiver may have adverse impacts on attachment. The change is quite limited when it is once established as secure or insecure (Kesebir et al., 2011). Insecure attachment is grouped in itself as avoidant, ambivalent and disorganized (Aydoğdu \& Çam, 2013; İnan, 2015; Fearon \& Roisman, 2017). While secure attachment is related with healthy processes, insecure attachment is related with psychopathologies such as behavioral disorder, substance addiction, antisocial personality disorder (Strathearn et al., 2019; Çam \& Aydoğdu, 2015; Kesebir et al., 2011).

Insecure attachment develops an inclination towards addiction due to the use of emotion regulation strategies focused on emotion or avoidance (Sümer et al., 2015). Even though more heterogeneous results related with alcohol have been obtained with the ambivalent attachment style at the forefront in the literature dominated mostly by studies on addiction and attachment with adolescent groups, avoidant attachment style has been frequently reported in relation with substance especially heroin (Schindler, 2019; Schindler et al, 2005).

It is also put forth that personality traits are related with starting, continuing and addiction of substance use (Başay, Yüncü, Başay, Öztürk \& Aydın, 2016; Akvardar et al., 2005). Craig (1979, 1982a) carried out a two-stage review on many studies utilizing the Minnesota Multiphasic Personality Inventory (MMPI) in which personality differences have been examined in sub-groups formed based on various characteristics in heroin addiction. Accordingly; it has been reported that high ratios of psychopathologies have been observed in substance addiction, that the psychopathy-sociopathy (psychopathic deviation) measurements are frequently high followed by depression and mania measurements and that only $5 \%$ of the MMPI profiles are in the normal interval. The detection of psychosis and neuroses in MMPI profiles has been indicated to be a rare case. In addition, while the profiles of addict individuals generally include self-assured, frightening, hostile and depressive emotions, appearance of extroversion and self-confidence also attracts attention (Craig, 1979, 1982a).

The relationship between insecure attachment and psychopathology has been examined in various groups, and comments have been made that they have causality, similarity and mediating roles among them (Sümer et al., 2009). In the light of all these findings, we are of the opinion that insecure attachment styles and psychopathological personality traits are observed more frequently in patients who use heroin as one of the most frequently used addictive substances today. In addition, we think that when looking at the possible relationship between insecure attachment and personality traits from the addiction perspective, we can reach results that predict the development of addiction.

The aim of the present study was to compare the attachment styles and personality traits of patients undergoing inpatient treatment for heroin use disorder (HUD) with those of the healthy control group. To the best 
of our knowledge, our study is the first that evaluates the relationship between the attachment styles and personality traits in heroin addict patients..

\section{Methods \\ Participants}

This study was planned in a case-control design. A total of 52 male patients aged 18 and above were included as the patient group in the study who were diagnosed with HUD according to DSM-5 diagnostic criteria undergoing inpatient treatment at the Pamukkale University Faculty of Medicine Psychiatry Department Alcohol and Drug Addiction Research, Treatment and Education Center at June 2019 - January 2020 . The study was completed with 29 patients, because 15 patients had an invalid MMPI test and 8 patients had missing attachment scales data. A total of 47 healthy hospital employees at similar age and gender, with no heroin use history made up the control group. Data from 34 controls were included in the study, since 8 controls were invalidated in the MMPI test and data on attachment scales for 5 controls were missing. Individuals with mental retardation and other psychiatric disorders were evaluated with psychiatric interview and excluded from the study.

\section{Measurement Tools}

The sociodemographic data form prepared by the researchers, MMPI and Experiences in Close Relationships-Revised (ECR-R) were applied on the participants in the patient and control groups.

Minnesota Multiphasic Personality Inventory (MMPI) The test was first developed and used by the Minnesota University in 1943. It is an objective personality inventory developed by Hathawey and Kinley (Aktaş et al., 2016). It is the most frequently used test for the structural evaluation of personality (Taymur \& Türkçapar, 2012). Turkish adaptation and standardization has been carried out by Savaşır (1981) whereas the validity study has been carried out by Erol (1982). MMPI; is an inventory aiming to provide an objective assessment of the personal and social adjustment which is comprised of 566 items for which true, false and don't know options can be selected. It consists of a total of 13 sub-tests including 10 for personality including hypochondriasis, depression, hysteria, psychopathic deviate, masculinity-femininity, paranoia, psychasthenia, schizophrenia, hypomania, social introversion and three validity tests of $\mathrm{F}$ (infrequency), $\mathrm{K}$ (correction), L (lie). The reliability value of the test was determined to vary between 0.51 and 0.89 (Savaşır, 1981; Erol, 1982).

\section{Experiences in Close Relationships-Revised (ECR-R)}

It is a 7-point Likert type scale developed by Fraley, Waller \& Brennan (2000). It has been developed for the measurement of the emotions and opinions of the individuals regarding their romantic relationships as well as the dimensions of adult attachment. The scale is comprised of 36 items in total including 18 items that measure the ambivalent attachment dimension and 18 items that measure the avoidant attachment dimension.
While the avoidant attachment dimension is calculated by taking the average of the even numbered items, ambivalent attachment dimension is calculated by taking the average of the odd numbered items. Scale items numbered 4, 8, 16, $17,18,20,21,22,24,26,30,32,34$ and 36 are reverse coded. The Turkish reliability and validity study for the scale has been carried out by Selçuk, Günaydın, Sümer \& Uysal (2005). The Cronbach alpha value of the scale was .90 for the avoidance dimension and .86 for the ambivalent dimension. Test - retest reliability value of the scale was determined .81 for avoidance dimension and .82 for ambivalent dimension (Selçuk et al., 2005).

\section{Process}

The sociodemographic data form and ECR-R scale were applied by a psychiatrist with face-to-face interview technique. The MMPI test was administered and interpreted by a psychologist who is trained and experienced in testing. The test application time is approximately 1.5 hour and the answers were scored by using the "MMPI Evaluation Book" (Oral \& Ceyhun, 2003). Both the psychologist and the psychiatrist were working in the clinic where the patients were treated.

\section{Data Analysis}

Statistical Package for the Social Sciences (SPSS v21, Chicago, Illinois, USA) software was used during the present study for statistical analysis of the acquired data. Frequency (n), percentage (\%), mean (mean) and standard deviation (SD) were used as descriptive statistics. Independent $\mathrm{T}$ test was used for the comparison of quantitative data when the data fit normal distribution and the Mann Whitney U test was used when the data did not fit normal distribution. Shapiro-Wilk normality test along with Skewness, Kurtosis coefficients were used for determining whether the data fit normal distribution or not. The relation between the variables was examined via Pearson Correlation analysis. Statistical significance was accepted as $\mathrm{p}<0.05$ for all tests in the $95 \%$ confidence interval.

\section{Ethics Council Approval}

The present study has been carried out in accordance with the Helsinki Declaration and has been approved with the decree by the Pamukkale University Ethics Council dated 21/05/2019 and numbered 10.

\section{Results}

Mean age for the patient and control groups was $22.9 \pm 4.8$ $(18-39)$ and $23.2 \pm 4.5$ (18-36) respectively $(\mathrm{U}=523.000$, $\mathrm{z}=0.416, \mathrm{p}=0.677)$. It was determined that $72.4 \%(\mathrm{n}=21)$ of the patient groupare single, $27.6 \%(\mathrm{n}=8)$ are married, $58.6 \%(n=17)$ are primary school graduates, $41.4 \%(n=12)$ are high school graduates, $55.2 \%(\mathrm{n}=16)$ are unemployed, $93.1 \%(n=27)$ live with their nuclear family, $6.9 \%(n=2)$ have a scattered family structure. Sociodemographic characteristics are presented in Table 1. 
Table 1.

Sociodemographic characteristics of the patient group

\begin{tabular}{llll}
\hline & & $\mathbf{n}$ & \% \\
\hline Marital status & Single & 8 & 27.6 \\
\multirow{2}{*}{ Education } & Married & 21 & 72.4 \\
& Primary school & 17 & 58.6 \\
Working status & High school & 12 & 41.4 \\
& Working & 13 & 44.8 \\
Family structure & Unemployed & 16 & 55.2 \\
& Nuclear family & 27 & 93.1 \\
Age & Scattered family & 2 & 6.9 \\
\hline
\end{tabular}

* Min: Minimum; Max: Maksimum; n: Number; SD: Standart deviation

It was observed when the data on heroin use were examined that the age of starting substance use is 17.6 \pm 4.2 (13-28), disease duration is $5.3 \pm 2.6(1-12)$ years while it was also observed with regard to the means of substance use that $58.6 \%(n=17)$ prefer inhalation, $41.4 \%(n=12)$ prefer inhalation and intravenous injection (Table 2). Of the patients, $44.8 \%(n=13)$ had a history of hospitalization due to addiction, $13.8 \% \quad(n=4)$ were diagnosed with hepatitis $\mathrm{C}$ and $65.5 \%(\mathrm{n}=19)$ had a good treatment compliance (Table 2).

Table 2.

Features of heroin use in the patient group

\begin{tabular}{llll}
\hline & & n & \% \\
\hline Heroin use & Inhalation & 17 & 58.6 \\
Hospitalization & İnhalation and intravenous injection & 12 & 41.4 \\
& Yes & 13 & 44.8 \\
Diagnosed with hepatitis C & No & 16 & 55.2 \\
& Yes & 4 & 13.8 \\
Treatment compliance & No & 25 & 86.2 \\
& Good & 19 & 65.5 \\
The age of starting substance use & Poor & 10 & 34.5 \\
Disease duration (year) & & Mean \pm SD & Min-max \\
\hline
\end{tabular}

Min: Minimum; Max: Maksimum; n: Number; SD: Standart deviation

MMPI scale scores were compared for the patient and control groups. L, F, masculinity-femininity, psychasthenia and hypomania were observed to be similar ( $>0.05$ ). While hypochondriasis, depression, hysteria, psychopathic deviate, paranoia, schizophrenia and social introversion scores were observed to be high at statistically significant levels in the patient group; $\mathrm{K}$ was higher in the control group (Table 3). The two groups were observed to be similar with regard to ambivalent and avoidant attachment styles (respectively $\mathrm{p}=0.086, \mathrm{p}=0.392$ ). Even though it was not reflected in the statistics, ambivalent attachment scores were higher in the patient group (Table $3)$.

Table 3.

Comparison of patient and control groups according to MMPI sub-tests and ECR-R (attachment styles)

\begin{tabular}{lllll}
\hline & $\begin{array}{l}\text { Patient } \\
\text { Mean } \pm \text { SD }\end{array}$ & $\begin{array}{l}\text { Control } \\
\text { Mean } \pm \text { SD }\end{array}$ & t & P \\
\hline MMPI sub-tests & & & & 0.449 \\
L (lie) & $48.3 \pm 12.1$ & $46.2 \pm 9.4$ & 0.762 & 0.351 \\
F (infrequency) & $60.1 \pm 16.3$ & $56.0 \pm 17.5$ & 0.940 & $\mathbf{0 . 0 1 4}$ \\
K (correction) & $42.8 \pm 9.9$ & $49.1 \pm 9.7$ & -2.517 & $\mathbf{0 . 0 2 4}$ \\
Hypochondriasis & $62.9 \pm 12.2$ & $55.5 \pm 12.8$ & 2.320 & $\mathbf{0 . 0 0 1}$ \\
Depression & $61.6 \pm 11.1$ & $52.0 \pm 10.4$ & 3.491 & $\mathbf{0 . 0 0 2}$ \\
Hysteria & $62.7 \pm 9.4$ & $53.7 \pm 11.6$ & 3.311 & $\mathbf{0 . 0 0 0}$ \\
Psychopathic deviate & $63.6 \pm 11.5$ & $52.0 \pm 12.1$ & 3.884 & 0.428 \\
Masculinity-femininity & $40.7 \pm 10.7$ & $38.7 \pm 9.1$ & 0.798 & $\mathbf{0 . 0 4 0}$ \\
Paranoia & $58.3 \pm 13.8$ & $51.5 \pm 11.6$ & 2.104 & 0.060 \\
Psychasthenia & $57.5 \pm 11.7$ & $52.0 \pm 11.0$ & 1.918 & $\mathbf{0 . 0 0 9}$ \\
Schizophrenia & $57.7 \pm 11.3$ & $50.1 \pm 10.8$ & 2.712 & 0.132 \\
Hypomania & $56.9 \pm 7.5$ & $53.2 \pm 11.7$ & 1.528 & $\mathbf{0 . 0 3 0}$
\end{tabular}




\begin{abstract}
Attachment style (ECR-R)
Ambivalent attachment

$3.63 \pm 1.32$

$3.12 \pm 0.98$

1.748

0.086

Avoidant attachment

$2.44 \pm 0.93$

$2.64 \pm 0.85$

$-0.862$

0.392

D: Standart deviation; t: Independent T test

While a strong and positive correlation was determined in the patient group between ambivalent attachment and F, hysteria, depression, paranoia, psychasthenia, schizophrenia and social introversion $(\mathrm{p}<0.05)$; a negative and moderate relationship was observed with the $\mathrm{L}$ and a negative and strong correlation was observed with the $\mathrm{K}$ $(\mathrm{p}<0.05)$. While a positive and moderate correlation was observed between ambivalent attachment and $\mathrm{F}$,

psychopathic deviate and social introversion in the control group $(\mathrm{p}<0.05)$. A moderate and positive relation was observed between avoidant attachment and psychasthenia in the patient group, while a strong correlation was observed with the social introversion $(p<0.05)$. Whereas a positive and moderate correlation was determined in the control group between avoidant attachment and depression and paranoia $(\mathrm{p}<0.05)$ (Table 4$)$.
\end{abstract}

Table 3.

Comparison of patient and control groups according to MMPI sub-tests and ECR-R (attachment styles)

\begin{tabular}{llllll}
\hline & & \multicolumn{2}{c}{ Ambivalent } & attachment & \multicolumn{2}{c}{ Avoidant attachment } \\
& & Patient & Control & -0.145 & Control \\
\hline L (lie) & $\mathbf{r}$ & -0.433 & -0.310 & 0.090 \\
F (infrequency) & $\mathbf{p}$ & $\mathbf{0 . 0 1 9}$ & 0.075 & 0.452 & 0.611 \\
& $\mathbf{r}$ & 0.638 & 0.375 & 0.315 & 0.065 \\
K (correction) & $\mathbf{p}$ & $\mathbf{0 . 0 0 0}$ & $\mathbf{0 . 0 2 9}$ & -0.259 & -0.273 \\
& $\mathbf{r}$ & -0.542 & -0.320 & 0.176 & 0.118 \\
Hypochondriasis & $\mathbf{p}$ & $\mathbf{0 . 0 0 2}$ & 0.065 & 0.315 & 0.090 \\
& $\mathbf{r}$ & 0.496 & -0.160 & 0.096 & 0.613 \\
Depression & $\mathbf{p}$ & $\mathbf{0 . 0 0 6}$ & 0.366 & 0.237 & 0.447 \\
& $\mathbf{r}$ & 0.570 & 0.317 & 0.215 & $\mathbf{0 . 0 0 8}$ \\
Hysteria & $\mathbf{p}$ & $\mathbf{0 . 0 0 1}$ & 0.068 & 0.271 & 0.022 \\
& $\mathbf{r}$ & 0.291 & -0.167 & 0.156 & 0.903 \\
Psychopathic deviate & $\mathbf{p}$ & 0.126 & 0.346 & -0.003 & 0.291 \\
Masculinity-femininity & $\mathbf{r}$ & 0.317 & 0.385 & 0.988 & 0.095 \\
Paranoia & $\mathbf{p}$ & 0.094 & $\mathbf{0 . 0 2 4}$ & 0.045 & 0.238 \\
Psychasthenia & $\mathbf{r}$ & 0.110 & 0.167 & 0.815 & 0.175 \\
Schizophrenia & $\mathbf{p}$ & 0.571 & 0.344 & 0.069 & 0.355 \\
Hypomania & $\mathbf{r}$ & 0.514 & 0.273 & 0.722 & $\mathbf{0 . 0 4 0}$ \\
Social introversion & $\mathbf{p}$ & $\mathbf{0 . 0 0 4}$ & 0.119 & 0.479 & 0.276 \\
& $\mathbf{r}$ & 0.642 & 0.229 & $\mathbf{0 . 0 0 9}$ & 0.114 \\
& $\mathbf{p}$ & $\mathbf{0 . 0 0 0}$ & 0.193 & 0.250 & 0.155 \\
& $\mathbf{r}$ & 0.528 & 0.223 & 0.191 & 0.380 \\
& $\mathbf{p}$ & $\mathbf{0 . 0 0 3}$ & 0.204 & -0.325 & 0.236 \\
& $\mathbf{r}$ & 0.038 & -0.268 & 0.085 & 0.178 \\
\end{tabular}

r: Pearson correlation value

\section{Discussion}

Many of the MMPI sub-tests were observed to increase in the patient group compared with the controls as a result of the present study aiming to compare the attachment styles and personality traits of the patients diagnosed with HUD undergoing inpatient treatment with the healthy control group. Hypochondriasis, depression, hysteria, psychopathic deviate, paranoia, schizophrenia and social introversion were observed to be higher at a statistically significant level in the patient group. Whereas attachment styles were observed to be similar in both groups. While ambivalent attachment was determined to be related with hysteria, depression, schizophrenia, paranoia, psychasthenia and social introversion in the patient group; avoidant attachment was determined to be related with psychasthenia and social introversion.
It is known that personality disorders are detected at a higher rate in patients who apply to addiction polyclinics compared to the general population (Casadio et al., 2014). It has been observed that Anglin, Weisman \& Fisher (1989) have carried out a review study examining the MMPI profiles in narcotic addicts and making comparisons between many characteristics such as sociodemographic, gender, diagnosis, ethnic structure as a result of which contradictory results have been obtained. In short, even though there is not a personality specific to substance dependence, it may be stated that some common characteristics and the probability of being diagnosed with personality disorder are high. For example, it has been determined as a result of various studies that psychopathic deviate, K, hypomania, hypochondriasis, depression, hysteria, psychasthenia, schizophrenia, social introversion, paranoia scores are high at statistically significant levels in heroin, cocaine, inhalant, cannabis, ecstasy ad methamphetamine addiction (Başay et al., 
2016; Galankin et al., 2018, Gerra et al., 2008; Weybrew, 1996).

Craig $(1979,1982 a)$ reported in the review study that many sub-scales have increased in the sub-groups prepared based on the various characteristics of heroin dependence, drawing attention to the statistically significant increase in psychopathic deviate and depression compared with the controls. Similarly, it has been determined in another study that there is an increase in all MMPI scores in the heroin dependent patient group in comparison with the controls. The highest scores were observed in the masculinityfemininity, hypomania and schizophrenia (Gerra et al., 2008). MMPI profiles of heroin dependent individuals were examined before and after a rehabilitation program during the study by Galankin et al. (2018) as a result of which psychopathologic MMPI profiles were observed in all individuals with the highest increases observed in psychopathic deviate, paranoia, psychasthenia, schizophrenia and hypomania.

Similar with the findings in literature, all MMPI sub-scales excluding masculinity-femininity, psychasthenia and hypomania were observed to be high in the heroin dependent patients in our study compared with the healthy controls indicating the prevalence of psychopathology. In this case, the presence of a prevalent psychopathological pattern can be mentioned even though there is not a typical personality pathology for dependence.

Insecure attachment established with the caregiver during the childhood period may be indicative with regard to substance use and displaying risky behaviors in later periods (Aydoğdu \& Çam, 2013). However, it is still unclear which insecure attachment style is related with dependence (Sümer et al., 2015). The frequency of avoidant, dismissing, fearful and preoccupied attachment has been mentioned in studies in which different scales have been used for attachment (Çam \& Aydoğdu, 2015; Cömert \& Ögel, 2014; Bülbül \& Odac1, 2018; Schindler et al, 2005). Fearful-avoidant attachment has been observed most frequently in heroin dependent patients (Schindler, 2019). Even though ambivalent attachment was observed more frequently among the patient and control groups in our study, a statistically significant difference could not be observed. This may be related with the low number of cases. Individuals who experience attachment anxieties develop an excessive attention and sensitivity. "Clinging on each other" is the best way to suppress anxiety for these individuals who continuously seek security. They may move on to using substances or different stimulants in cases when this is not possible (Sümer et al., 2015).

In studies examining attachment and personality disorders in the literature, it has been concluded that secure attachment is often negatively correlated with all personality types. Also, disorganized/unresolved attachment was found to be positively correlated with every personality types. Avoidant attachment is often associated with paranoid, schizoid and schizotypal personality types, while ambivalent attachment is associated with borderline, histrionic and dependent personality types (Smith \& South, 2020; Sinha \& Sharan, 2007). There are also studies that cannot find a clear relationship between personality and attachment (NakashEisikovits, Dutra \& Westen, 2002; Fossati et al., 2001). In our study, while there was a relationship between ambivalent attachment and more personality patterns (hysteria, depression, schizophrenia, paranoia, psychasthenia and social introversion) in the HUD group, less personality patterns (psychasthenia and social introversion) were found to be associated with avoidant attachment.

Psychopathology prevalence observed as a result of our study on HUD patients attracts attention as a precursor for dependence compared with insecure attachment. It will be possible to interpret the common points with the development of dependence when personality is considered as the complete set of characteristics including the innate as well as those acquired via environmental factors throughout the development period. The effect of family decreases as the individual grows up while the effects of variables such as friends, school, social environment increase (Özdemir, Özdemir, Kadak \& Nasıroğlu, 2012). Problems related with these psychosocial factors may act as a risk factor for developing dependence on the continuously developing personality pattern. Even though the boundaries of attachmentdependence-personality triangle cannot be distinguished clearly, the effect of insecure attachment on personality development which can be considered as a dynamic variable throughout the development period of the individual may shift during the initial periods of life in favor of dependence due to the impacts of the adverse environmental conditions.

The small sample size attracts attention as a limitation of our study. The fact that the scale consists of 566 questions, time-consuming application and interpretation process and that it is a comprehensive assessment method interpreted by the evaluator may have affected the number of participants. Also the high number of invalid MMPI tests in both patient and control groups, especially in the patient group, also has a significant effect on the small sample size. Even so, inclusion of the validity sub-scales especially for MMPI and the assessment by a single interpreted increases the reliability of the data.

In conclusion; an increase was observed in the MMPI scores in general which indicates psychopathology in patients diagnosed with HUD. It can be stated that the increase of sub-scales indicating psychopathologic patterns such as psychopathic deviate and paranoia predict heroin dependence more subject to the attachment styles established during the first three years of life. Due to the increasing number of patients diagnosed with HUD, difficulties in treatment and the obvious importance of addiction prevention studies, this study is important in terms of drawing attention to the development of addiction and showing the risk posed by personality patterns. The results contribute to the related literature based on the fact that they remind us the importance of adolescence during which personality development is shaped by environmental factors such as peers, school, social life while also leading us to think that psychosocial support such as guidance, education, rehabilitation that can be provided to individuals with psychopathologic patterns detected may divert them from the path towards dependence. It is recommended to evaluate the results with studies using different scales and methods (follow-up studies) with larger samples, in which the results can be repeated by examining the attachment styles in more detail. 


\section{Declarations}

\section{Ethics Approval and Consent to Participate}

The present study has been carried out in accordance with the Helsinki Declaration and has been approved with the decree by the Pamukkale University Ethics Council dated 21/05/2019 and numbered 10.

Consent for Publication

Not applicable.

\section{Availability of Data and Materials}

Data sets used and / or analyzed during the study can be obtained from the relevant author upon appropriate request.

\section{Competing Interests}

The author declares that no competing interests in this manuscript.

\section{Funding}

Not applicable.

\section{Authors' Contributions}

TTU, analyzed and interpretend the data and contributed writing of the article. FA, designed the study and interpretend the data, contributed writing of the article. GZ, monitored data collection and contributed writing of the article. CT monitored data collection, interpretend the data and contributed writing of the article. All authors have read and approved the final version of the article.

\section{Acknowledgements}

Not applicable.

\section{References}

Aktaş, E. A., Güriz, O., Kahilloğulları, A. K., Alpaslan, G., Cavdar, E., Dağdeviren, A. (2016). Diagnostic tools for personality disorders: A comparison. Journal of Cognitive Behavioral Psychotherapy and Research, 5(1), 22-27.

Akvardar, Y., Arkar, H., Akdede, B. B., Gül, S., Sarı, Ö., Tunca, Z. (2005). Personality Features of Patients with Alcohol Use Disorders. Journal of Dependence, 6(2), 53-59.

Anglin, M. D., Weisman, C. P., Fisher, D. G. (1989). The MMPI profiles of narcotics addicts. I. A review of the literature. International Journal of the Addictions, 24(9), 867-880.

Antonucci, L. A., Taurisano, P., Coppola, G., Cassibba, R. (2018). Attachment style: The neurobiological substrate, interaction with genetics and role in neurodevelopmental disorders risk pathways. Neuroscience \& Biobehavioral Reviews, 95, 515-527.

Aydoğdu, H., Çam, M. H. (2013). Comparison of the attachment styles, parent attitudes and social supports of normal adolescence and adolescence diagnosed with substance use disorder. Journal of Psychiatric Nursing, 4(3), 137-144.

Başay, Ö., Yüncü, Z., Başay, B. K., Öztürk, Ö., Aydın, C. (2016). Personality characteristics of adolescents with substance use disorders. Anatolian Journal of Psychiatry, 17(2), 127-135.

Bülbül, K., Odacı, H. (2018). Hopelessness, attachment style and family structure's predictive power in substance abuse proclivity among high school students. Turkish Journal of Clinical Psychiatry, 21(4), 360-369.

Casadio, P., Olivoni, D., Ferrari, B., Pintori, C., Speranza, E., Bosi, M., Belli, V., Baruzzi, L., Pantieri, P., Ragazzini, G., Rivola, F., \& Atti, A. R. (2014). Personality disorders in addiction outpatients: prevalence and effects on psychosocial functioning. Substance Abuse : Research and Treatment, 8, 17-24.

Cömert, I. T., Ögel, K. (2014). Attachment Styles of Adolescent Substance Users. Addicta: The Turkish Journal on Addictions, 1(1), 9-40.

Craig, R. J. (1979). Personality characteristics of heroin addicts: A review of the empirical literature with critique--part II. International Journal of the Addictions, 14(5), 607-626.

Craig, R. J. (1982). Personality characteristics of heroin addicts: Review of empirical research 1976-1979. International Journal of the Addictions, 17(2), 227-248

Çam, O., Aydoğdu, H. (2015). The evalution of attachment process in the context of adolescents diagnosed with substance use disorder. Çocuk ve Gençlik Ruh Sağlığı Dergisi, 22(1), 49-56.

Erol, N. (1982). Ülkemizdeki psikiyatrik hastalarda MMPI'ın geçerlik çalışması. Psikoloji Dergisi, 14, 15-23.

Fearon, R. M. P., Roisman, G. I. (2017). Attachment theory: progress and future directions. Current Opinion in Psychology, $15,131-136$.
Fossati, A., Donati, D., Donini, M., Novella, L., Bagnato, M., Maffei, C. (2001). Temperament, character, and attachment patterns in borderline personality disorder. Journal of Personality Disorders, 15(5), 390-402.

Fraley, R. C., Roisman, G. I. (2019). The development of adult attachment styles: Four lessons. Current Opinion in Psychology, 25, 26-30.

Fraley, R. C., Waller, N. G., Brennan, K. A. (2000). An item response theory analysis of self-report measures of adult attachment. Journal of Personality and Social Psychology, 78(2), 350-365.

Galankin, T., Lioznov, D., Nikolaenko, S., McNutt, L. A., Leckman-Westin, E., Smith, P. F. (2018). Psychological features of abstinent heroin users before and after rehabilitation in Saint Petersburg, Russia. BMC Research Notes, 11(1), 589.

Gerra, G., Bertacca, S., Zaimovic, A., Pirani, M., Branchi, B., Ferri, M. (2008). Relationship of personality traits and drug of choice by cocaine addicts and heroin addicts. Substance Use \& Misuse, 43(3-4), 317-330.

İnan, E. (2015). Narcissistic personality patterns and anxious attachment style: A case example. AYNA Klinik Psikoloji Dergisi, 2(1), 1-12.

Kesebir, S., Kavzoğlu, S. Ö., Üstündağ, M. F. (2011). Attachment and psychopathology. Current Approaches in Psychiatry, 3(2), 321-342.

Nakash-Eisikovits, O., Dutra, L., Westen, D. (2002). Relationship between attachment patterns and personality pathology in adolescents. Journal of the American Academy of Child and Adolescent Psychiatry, 41(9), 1111-1123.

Oral, N., Ceyhun, B. (2003). Minnesota çok yönlü kişilik envanteri - Değerlendirme kitabı. Ankara: Çizgi Tıp Yayınevi.

Özdemir, O., Özdemir, P. G., Kadak, M. T., Nasıroğlu, S. (2012). Personality development. Current Approaches in Psychiatry, 4(4), 566-589.

Savaşır, I. (1981). Minnesota çok yönlü kișilik envanteri el kitabı. Ankara: Sevinç Matbaası.

Schindler, A. (2019). Attachment and substance use disordersTheoretical models, empirical evidence, and implications for treatment. Frontiers in Psychiatry, 10, 727.

Schindler, A., Thomasius, R., Sack, P.M., Gemeinhardt, B. Küstner, U., Eckert, J. (2005). Attachment and substance use disorders: A review of the literature and a study in drug dependent adolescents. Attachment \& Human Development, 7(3), 207-228. 
Selçuk, E., Günaydın, G., Sümer, N., Uysal, A. (2005). A new scale developed to measure adult attachment dimensions: Experiences in Close Relationships-Revised (ECR-R) Psychometric evaluation in Turkish sample. Turkish Journal of Psychology, 8(16), 1-11.

Sinha, P., Sharan, P. (2007). Attachment and personality disorders. Journal of Indian Association for Child and Adolescent Mental Health, 3, 105-112.

Smith, M., South, S. (2020). Romantic attachment style and borderline personality pathology: A meta-analysis. Clinical Psychology Review, 75, 101781.

Strathearn, L., Mertens, C. E., Mayes, L., Rutherford, H., Rajhans, P., Xu, G., Potenza, M. N., Kim, S. (2019). Pathways relating the neurobiology of attachment to drug addiction. Frontiers in Psychiatry, 10, 737.

Sümer, N., Oruçlular, Y., Çarpar, T. (2015). Attachment and Addiction: Theoretical Framework and Literature Review. Journal of Dependence, 16(4), 192-209.
Sümer, N., Ünal, S., Selçuk, E., Kaya, B., Polat, R., Cekem, B. (2009). Attachment and Psychopathology: Relationship between Adult Attachment and Depression, Panic Disorder, and Obsessive Compulsive Disorder. Turkish Journal of Psychology, 24, 38-45.

Szepsenwol, O., Simpson, J. A. (2019). Attachment within life history theory: An evolutionary perspective on individual differences in attachment. Current Opinion in Psychology, 25, 6570.

Taymur, İ., Türkçapar, M. H. (2012). Personality: Description, Classification and Evaluation. Current Approaches in Psychiatry, $4(2), 154-177$

Weybrew, B.B. (1996). MMPI patterns of physically and psychologicall dependent drug abusers. Perceptual and Motor Skills, 83(2), 60-642. 